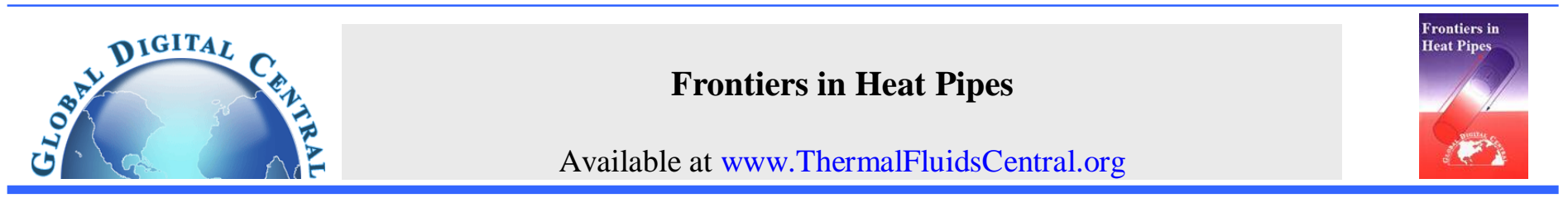

\title{
HEAT PIPE HEAT EXCHANGER FOR HIGH TEMPERATURE NUCLEAR REACTOR TECHNOLOGY
}

\author{
R.T Dobson*, R Laubscher \\ Department of Mechanical Engineering, University of Stellenbosch, Stellenbosch \\ Private Bag X1, MATIELAND 7602, South Africa
}

\begin{abstract}
When a high temperature nuclear reactor is used to supply process heat, nuclear regulators require an intermediate heat transfer loop between the primary reactor coolant stream and the secondary process heat stream. A sodium-charged heat pipe heat exchanger design is presented that circumvents the need for an intermediate coolant loop. This is done by physically separating the reactor coolant and secondary coolant by two pipe walls, and a vapour section and a liquid section. This tritium diffusion resistant design for the re-heater, preheater, steam generator and super-heater heat supply system of a $232 \mathrm{MW}$-electrical pebble bed modular reactor heat source for a superheated Rankine power cycle is presented. A theoretical model was then used to produce preliminary design sizes (tube sizes, tube lengths, working fluid, etc.) for a sodium-charged heat exchanger to be used with a high temperature gas-cooled reactor.

Keywords: Heat pipe heat exchanger; sodium working fluid, tritium, high temperature, nuclear reactor.
\end{abstract}

\section{INTRODUCTION}

About 17 per cent of the world's electricity is produced by nuclear reactors, as compared with the 4 per cent produced by so-called renewable energy sources. The renewable sources have the disadvantage that their supply is not consistent and by and large depend on the weather. Nuclear power on the other hand has the disadvantage of having a poor public acceptance, but at this time is the only commercially viable non-fossil fuel source of energy. In an attempt to ensure an appropriate roadmap for future nuclear technology development a set of guide lines have been drawn up by the so-called Generation IV Nuclear Forum (US DOE, 2002). These guide lines may be summarised as being to:

- Ensure sustainability, focusing on waste management and resource utilization

- Ensure economic competiveness by reducing costs and financial risks

- Ensure and enhance the safe and reliable goals, improved accident management and minimization of consequences, investment protection and reduced need for off-site emergency response.

- Ensure proliferation resistance and physical protection by implementing means for controlling and securing nuclear material and nuclear facilities.

Together with these guidelines six nuclear power reactors systems were identified as the most attractive for further research and development, namely the Gas-Cooled Fast Reactor, Lead-Cooled Fast Reactor, Molten Salt Reactor, Sodium-Cooled Fast Reactor, SupercriticalWater-Cooled Reactor and the Very-High-Temperature Reactor Systems. An important characteristic of all these reactor systems is that they will operate at much higher temperatures than present-day pressurised and boiling water nuclear power reactors.

Corresponding author email: rtd@sun.ac.za
Higher temperature heat sources are becoming an ever-increasing imperative in the process industry for the production of various plastics, fertilisers, hydrogen generation, coal-to-liquid fuel and process heat. Current high temperature reactor technology is capable of producing reactor coolant temperatures in excess of $950{ }^{\circ} \mathrm{C}$. At these temperatures however, tritium which is a radioactive contaminant found in the reactor coolant stream, is able to contaminant the secondary stream by diffusing through the steel retaining walls in the heat exchanger between the reactor coolant and secondary coolant. [Tritium (H3) is a radioactive isotope of hydrogen and has a half-life for beta-decay of 246 days.] Further if equipment is contaminated with tritium, good nuclear-maintenance practice requires that 10 half-lives (about eight years) must elapse before ordinary maintenance operations are carried out. To circumvent the possibility of this tritium contamination of the secondary stream, regulatory authorities require that the system designer consider the incorporation of an intermediate heat exchange system as shown in Fig. 1a (IAEA, 1996). Figure 1b, on the other hand, shows the piping layout incorporating a heat pipe heat exchanger (HPHE), thereby obviating the need for an additional pump and pipe work and high pressure heat exchanger shell, but even adding an extra tritium diffusion barrier at, ostensibly, no extra cost. A drawing of such a heat pipe heat exchanger (HPHE) is shown in Fig 2. It consists of an enclosure That had been evacuated prior to charging it with a working fluid of which the lower half is filled with liquid and the upper part is its vapour. The hot and high pressure stream passes through tubes that are submerged in the liquid pool; and as this is where boiling occurs it may also be termed the evaporator section. In the condenser section the vapour condenses on the tubes in which the colder, but also high pressure, stream flows. In this section of the container the vapour condenses on the colder tubes; and hence is also termed the condenser section. The condensate collects along the lowest portion of the tube and then then falls, under the influence of gravity, as droplets back into the liquid pool. In this way latent heat is transfer with essentially no resistance to flow or pressure loss, reminiscent of the working 
fluid flow pattern in a closed two-phase thermosyphon-type (natural circulation) heat pipe.

Another advantage of this HPHE design is that the working fluid container need not be a pressure vessel; as the high pressure streams are conveniently contained in the small-diameter tubes. By an appropriate choice of the working fluid the pressure in the HPHE container may be

\section{Single phase shell-and-tube heat exchangers}
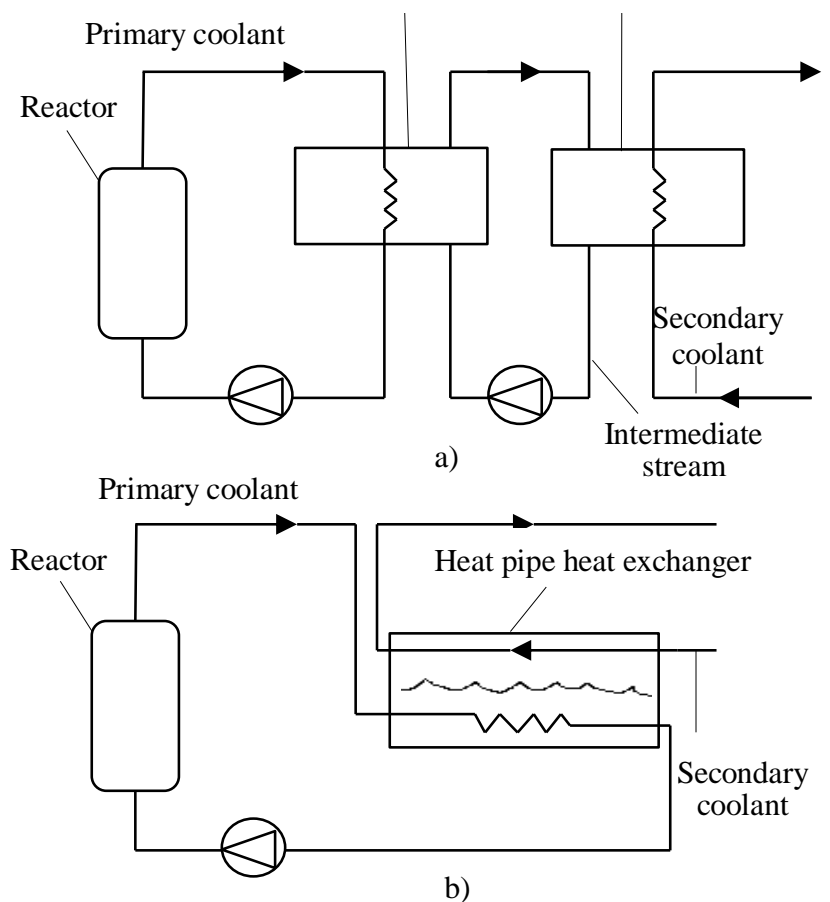

Fig. 1 Current regulatory power loop with intermediate heat exchange circuit (a), and heat pipe heat exchanger (b).

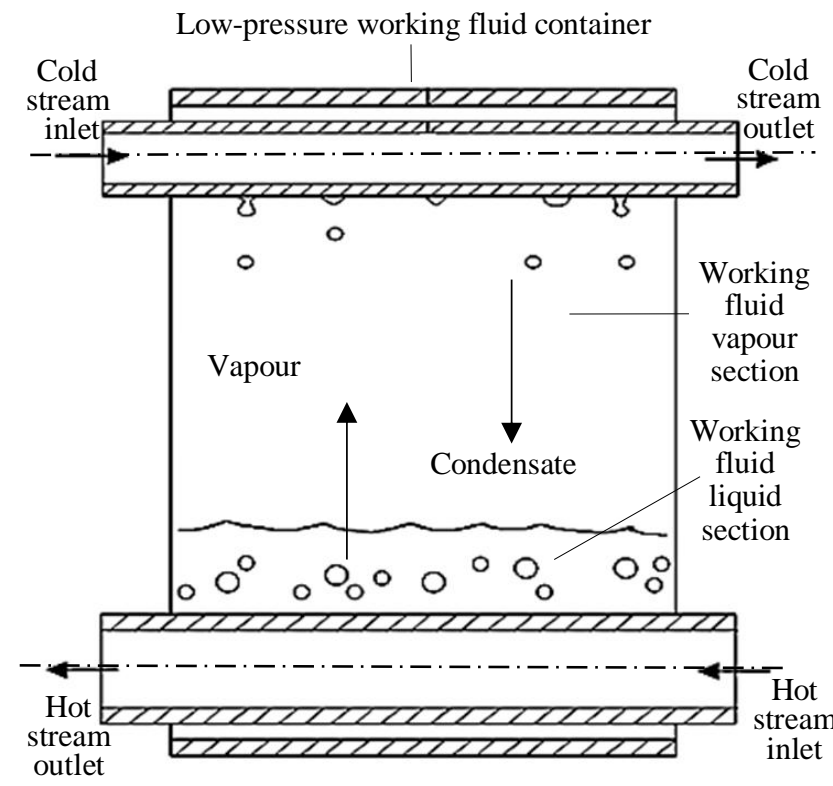

Fig. 2 Sectional view of a conceptual heat pipe heat exchanger in which the the hot and cold stream stream tubes pass through the working fluid container (only one evaporator and one only condenser tube are shown). designed to operate at more-or-less atmospheric pressure and thereby eliminating the need for any large-diameter high-pressure vessels.

Should any tritium diffuse through the higher temperature tubes, or for that matter any non-condensable gasses (NCGs) find their way into the working fluid the lighter gasses would find their way to the highest point in the container. Here the NCG may be conveniently extracted.

The objectives of this paper may now be summarised as being to:

- Present a design concept of a specially designed heat pipetype heat exchanger to completely eliminate the intermediate heat transfer circuit including the high-pressure heat exchanger, pipework and pump.

- Present the basic heat design features of the preheater, superheater and re-heater heat exchangers for an approximately 232

MWelectrical pebble bed modular reactor (PBMR) steam Rankine cycle electrical power generating unit.

To meet these objectives background design theory including working fluid choice, boiling and condensation thermal coefficients and the operating states are given in section 2.A summary of the simulation model is given in section 3 . The design results sizes are given in section 4 and finally in section 5 conclusions are drawn.

Table 1 Liquid metals used in heat pipes (Mills, 1995).

\begin{tabular}{|l|c|c|c|c|c|}
\hline $\begin{array}{l}\text { Working } \\
\text { fluid }\end{array}$ & $\begin{array}{c}\text { Melting } \\
\text { point, } \\
\text { at } 1 \mathrm{~atm} \\
{ }^{\circ} \mathrm{C}\end{array}$ & $\begin{array}{c}\text { Boiling } \\
\text { point } \\
\text { at } 1 \mathrm{~atm} \\
{ }^{\circ} \mathrm{C}\end{array}$ & $\begin{array}{c}\text { Latent } \\
\text { heat } \\
\mathrm{MJ} / \mathrm{kg}\end{array}$ & $\begin{array}{c}\text { Liquid } \\
\text { density } \\
\left(\mathrm{kg} / \mathrm{m}^{3}\right)\end{array}$ & $\begin{array}{c}\text { Useful } \\
\text { range }\left({ }^{\circ} \mathrm{C}\right)\end{array}$ \\
\hline Sodium & 98 & 883 & 3.9 & 900 & $600-1200$ \\
\hline Lithium & 180 & 1340 & 19.5 & 514 & $1000-1800$ \\
\hline Lead & 327 & 1746 & 0.9 & 10530 & $650-900$ \\
\hline Potassium & 64 & 759 & 2.0 & 814 & $500-1000$ \\
\hline
\end{tabular}

\section{BACKGROUND THEORY}

\subsection{Working Fluid}

High temperature nuclear reactor applications would typically require operating temperatures of between 650 and $950{ }^{\circ} \mathrm{C}$. From table 1 it is seen that sodium's useful working range is between 600 and $1200{ }^{\circ} \mathrm{C}$ and hence would be the working fluid of choice. Further at these temperatures sodium's saturated vapour pressure will be $15 \mathrm{kPa}$ and $960 \mathrm{kPa}$, respectively. These pressure are not too low or too high and thus the need for special high-vacuum equipment and specially designed high pressure vessels is eliminated (Faghri, 1995). Sodium is also compatible with typical high temperature steels.

\subsection{Boiling Heat Transfer Coefficient}

The boiling heat transfer coefficient is given by Shah (1992) as

$h_{\mathrm{b}}=\mathrm{C} \dot{q}^{0.7} \operatorname{Pr}^{\mathrm{m}}$

where $\operatorname{Pr}<0.001, \mathrm{C}=13.7$ and $\mathrm{m}=0.22, \operatorname{Pr}>0.001, \mathrm{C}=6.9$ and $\mathrm{m}=$ 0.12 . This correlation is for pool boing for liquid metals at pressures between 0.3 and $1000 \mathrm{kPa}$, reduced pressures of between $4.4 \times 10^{-6}$ and $2.4 \times 10^{-2}$ and heat fluxes of between 12 and $2800 \mathrm{~kW} / \mathrm{m}^{2}$.

\subsection{Condensation Heat Transfer Coefficient}

The laminar film condensation heat transfer coefficient is determined theoretically by using the force balance and energy balance on a liquid element within the film around the condenser tube, and not empirically using generalisations of data through correlations, as in the case of nucleate pool boiling (Mills, 1995). The heat transfer coefficient for a laminar condensate film is dependent on the thermal conductivity of the 
fluid medium and the film thickness that is formed on the condenser tube and is given as

$$
h_{\mathrm{c}}=\frac{k_{\mathrm{l}}}{\delta}
$$

where $\delta=\left(\frac{3}{4} \frac{\rho_{1} v_{1}^{2}}{\left(\rho_{1}-\rho_{\mathrm{v}}\right) \mathrm{g}} \frac{\mathrm{Re}}{\sin \phi}\right)^{1 / 3}$

and

$\operatorname{Re}=\left(\frac{4}{3} \frac{2 k_{1}\left(T_{\mathrm{sat}}-T_{\mathrm{S}}\right) \mathrm{d}}{\mu_{\mathrm{l}} h_{\mathrm{fg}}}\left[\frac{4}{3} \frac{\left(\rho_{\mathrm{l}}-\rho_{\mathrm{v}}\right) \mathrm{g}}{\rho_{\mathrm{l}} v_{1}^{2}}\right]^{\frac{1}{3}}(2.5872)\right)$

Integrating along the pipe to determine the average heat transfer is given by (Mill, 1995) as

Point 1, Water

$49.02{ }^{\circ} \mathrm{C}, 12 \mathrm{kPa}$

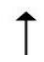

Point 7 Steam

$363{ }^{\circ} \mathrm{C}, 4.5 \mathrm{MPa}$

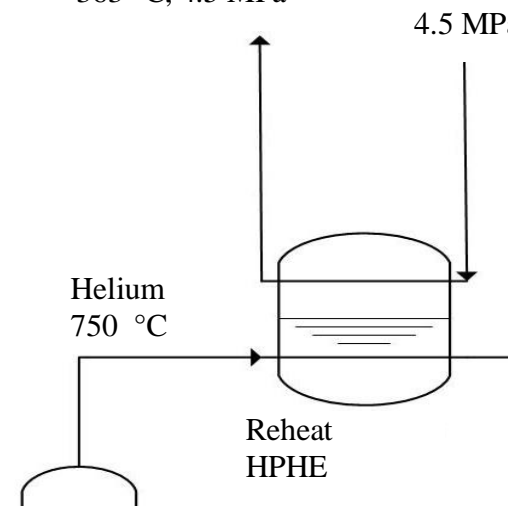

High

Temperature

gas reactor

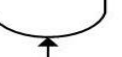

(20)

Helium $301.68^{\circ} \mathrm{C}$ $\bar{h}_{\mathrm{c}}=0.728 \frac{\left(\rho_{\mathrm{l}}-\rho_{\mathrm{v}}\right) \mathrm{g} h_{\mathrm{fg}} k_{1}^{3}}{\mathrm{~N} v_{1} \mathrm{D}\left(T_{\mathrm{sat}}-T_{\mathrm{s}}\right)}$

\subsection{Operating States}

Figure 3 gives a schematic layout drawing of a high temperature heat source for a $232 \mathrm{MW}$-electrical superheated Rankine cycle electrical power generating unit for a helium heating stream leaving the reactor at $750{ }^{\circ} \mathrm{C}$; with the quantitative values of the working point states given in table 2. This layout is based on the steam supply requirements for a conceptual design for a coal-to-liquid fuel processing plant (Botha, 2013). In Fig. 3 the conventional shell and tube preheater, superheater and reheater have been replaced by HPHEs, similar to the design shown in Fig. 2. The reactor is essentially a pebble bed modular reactor and the power unit is assumed to be a superheated Rankine cycle. [To improve power generation thermal efficiency a supercritical Brayton cycle with inlet pressures of between 20 and $30 \mathrm{MPa}$ and inlet temperature $950{ }^{\circ} \mathrm{C}$
Point 5

Saturated water

$566{ }^{\circ} \mathrm{C}, 15.1 \mathrm{MPa}$

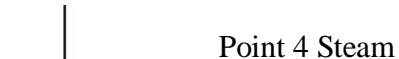

$342.68{ }^{\circ} \mathrm{C}, 15.1 \mathrm{MPa}$

Point 3

Saturated water

$342.68^{\circ} \mathrm{C}, 15.1 \mathrm{MPa}$

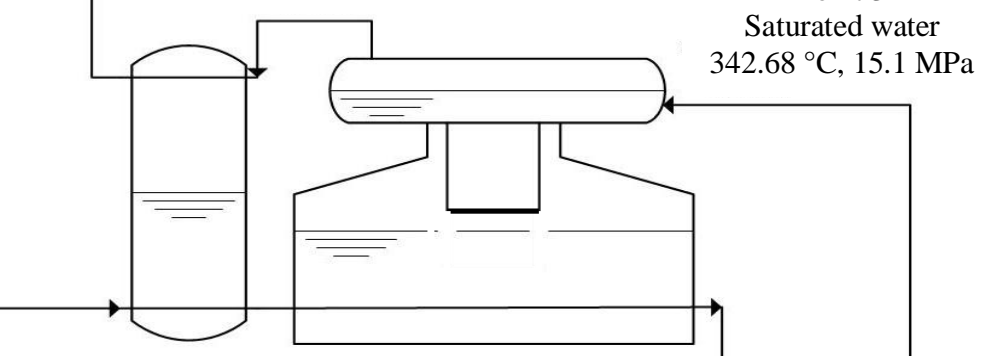

Table 2 Thermodynamic properties at each point indicated in figure 3.

\begin{tabular}{|c|c|c|c|c|c|}
\hline Point & $T,{ }^{0} \mathrm{C}$ & $P, \mathrm{MPa}$ & $s, \mathrm{~kJ} / \mathrm{kg} . \mathrm{K}$ & $h, \mathrm{~kJ} / \mathrm{kg}$ & $x, \%$ \\
\hline 1 & 49.074 & 0.012 & 0.69148 & 205.462 & $<0$ \\
\hline 2 & 205 & 15.1 & 2.356275 & 880.3575 & $<0$ \\
\hline 3 & 342.68 & 15.1 & 3.6848 & 1610.3 & $0.01 \%$ \\
\hline 4 & 342.68 & 15.1 & 5.3108 & 2610.8 & $100.00 \%$ \\
\hline 5 & 566 & 15.1 & 6.56933 & 3491.856 & $>100$ \\
\hline 6 & 364.085 & 4.5 & 6.56933 & 3116.487 & $>100$ \\
\hline 7 & 566 & 4.5 & 7.217364 & 3592.53 & $>100$ \\
\hline 8 & 49.074 & 0.012 & 7.217364 & 2307.832 & $88.20 \%$ \\
\hline
\end{tabular}

Table 3 Inlet/outlet temperatures for each of the required heat exchangers and the required heat transfer rate from the helium.

\begin{tabular}{|c|c|c|}
\hline \multicolumn{3}{|c|}{ Preheater HPHE } \\
\hline$\dot{\mathrm{Q}}_{\mathrm{ht}}$ & 49.5 & $\mathrm{MW}$ \\
\hline $\mathrm{T}_{\text {steam,in }}$ & 205 & ${ }^{\circ} \mathrm{C}$ \\
\hline $\mathrm{T}_{\text {steam,out }}$ & 342.68 & ${ }^{\circ} \mathrm{C}$ \\
\hline \multicolumn{3}{|c|}{ Superheater HPHE } \\
\hline$\dot{\mathrm{Q}}_{\text {ht }}$ & 59.65 & $\mathrm{MW}$ \\
\hline $\mathrm{T}_{\text {steam,in }}$ & 342.68 & ${ }^{\circ} \mathrm{C}$ \\
\hline $\mathrm{T}_{\text {steam,out }}$ & 566 & ${ }^{\circ} \mathrm{C}$ \\
\hline \multicolumn{3}{|c|}{ Reheat HPHE } \\
\hline$\dot{\mathrm{Q}}_{\text {ht }}$ & 32.121 & $\mathrm{MW}$ \\
\hline $\mathrm{T}_{\text {steam,in }}$ & 364.08 & ${ }^{\circ} \mathrm{C}$ \\
\hline $\mathrm{T}_{\text {steam,out }}$ & 566 & ${ }^{\circ} \mathrm{C}$ \\
\hline
\end{tabular}


Table 4 Design specification for preheater heat pipe heat

\begin{tabular}{|c|c|c|}
\hline \multicolumn{3}{|c|}{ Preheater HPHE } \\
\hline$\dot{\mathrm{m}}_{\text {steam }}$ & 67.745 & $\mathrm{~kg} / \mathrm{s}$ \\
\hline$\dot{\mathrm{m}}_{\text {helium }}$ & 89.30133 & $\mathrm{~kg} / \mathrm{s}$ \\
\hline $\mathrm{N}_{\text {tubes }}$ & 200 & number \\
\hline $\mathrm{P}_{\text {HPHE }}$ & 0.04987 & $\mathrm{bar}$ \\
\hline OD $_{\text {COND }}$ & 0.08 & $\mathrm{~m}$ \\
\hline OD $_{\text {EVAP }}$ & 0.2 & $\mathrm{~m}$ \\
\hline $\mathrm{T}_{\text {steam,in }}$ & 364.085 & ${ }^{\circ} \mathrm{C}$ \\
\hline $\mathrm{T}_{\text {steam,out }}$ & 564.837 & ${ }^{\circ} \mathrm{C}$ \\
\hline $\mathrm{T}_{\text {helium,in }}$ & 750 & ${ }^{\circ} \mathrm{C}$ \\
\hline $\mathrm{T}_{\text {helium,out }}$ & 679.962 & ${ }^{\circ} \mathrm{C}$ \\
\hline$\dot{\mathrm{Q}}_{\text {in }}$ & 32.638 & $\mathrm{MW}$ \\
\hline $\mathrm{L}_{\text {tube }}$ & 14 & $\mathrm{~m}$ \\
\hline \multicolumn{2}{c}{}
\end{tabular}

Table 5 Design specification for the superheat heat pipe heat exchanger

\begin{tabular}{|c|c|c|}
\hline \multicolumn{3}{|c|}{ Super heater HPHE } \\
\hline$\dot{\mathrm{m}}_{\text {steam }}$ & 67.745 & $\mathrm{~kg} / \mathrm{s}$ \\
\hline$\dot{\mathrm{m}}_{\text {helium }}$ & 89.30133 & $\mathrm{~kg} / \mathrm{s}$ \\
\hline $\mathrm{N}_{\text {tubes }}$ & 320 & number \\
\hline $\mathrm{P}_{\text {HPHE }}$ & 0.02035 & bar \\
\hline $\mathrm{OD}_{\text {COND }}$ & 0.08 & $\mathrm{~m}$ \\
\hline $\mathrm{OD}_{\text {EVAP }}$ & 0.2 & $\mathrm{~m}$ \\
\hline $\mathrm{T}_{\text {steam,in }}$ & 342.696 & ${ }^{\circ} \mathrm{C}$ \\
\hline $\mathrm{T}_{\text {steam,out }}$ & 563.9329 & ${ }^{\circ} \mathrm{C}$ \\
\hline $\mathrm{T}_{\text {helium,in }}$ & 679.6595 & ${ }^{\circ} \mathrm{C}$ \\
\hline $\mathrm{T}_{\text {helium,out }}$ & 553.798 & ${ }^{\circ} \mathrm{C}$ \\
\hline$\dot{\mathrm{Q}}_{\text {in }}$ & 58.871 & $\mathrm{MW}$ \\
\hline $\mathrm{L}_{\text {tube }}$ & 25 & $\mathrm{~m}$ \\
\hline
\end{tabular}

Table 6 Design specification for reheat heat pipe heat exchanger

\begin{tabular}{|c|c|c|}
\hline \multicolumn{3}{|c|}{ Reheater HPHE } \\
\hline$\dot{\mathrm{m}}_{\text {steam }}$ & 67.745 & $\mathrm{~kg} / \mathrm{s}$ \\
\hline$\dot{\mathrm{m}}_{\text {helium }}$ & 89.30133 & $\mathrm{~kg} / \mathrm{s}$ \\
\hline $\mathrm{N}_{\text {tubes }}$ & 400 & number \\
\hline $\mathrm{P}_{\text {HPHE }}$ & 0.03162 & $\mathrm{bar}$ \\
\hline $\mathrm{OD}_{\text {COND }}$ & 0.08 & $\mathrm{~m}$ \\
\hline $\mathrm{OD}_{\text {EVAP }}$ & 0.2 & $\mathrm{~m}$ \\
\hline $\mathrm{T}_{\text {steam,in }}$ & 205.04 & ${ }^{\circ} \mathrm{C}$ \\
\hline $\mathrm{T}_{\text {steam,out }}$ & 340.377 & ${ }^{\circ} \mathrm{C}$ \\
\hline $\mathrm{T}_{\text {helium,in }}$ & 407.883 & ${ }^{\circ} \mathrm{C}$ \\
\hline $\mathrm{T}_{\text {helium,out }}$ & 300.583 & ${ }^{\circ} \mathrm{C}$ \\
\hline$\dot{\mathrm{Q}}_{\text {in }}$ & 50.237 & $\mathrm{MW}$ \\
\hline $\mathrm{L}_{\text {tube }}$ & 35 & $\mathrm{~m}$ \\
\hline
\end{tabular}

could have been considered. At present, but with somewhat lower inlet temperatures of between 550 and $700{ }^{\circ} \mathrm{C}$, there are some 600 fossil fuelled supercritical power stations around the world (Zhao Zongrang, 2005). In the context in which this paper is applied, namely a coal-toliquid (CTL) fuel plant, a superheated Rankine (rather than a supercritical cycle) was considers appropriate. In Botha's (2013) study a thermally-less efficient plant was considered from a nuclear reactor proof-of-concept point of view, wherein overall plant efficiency but mainly reliability, carbon footprint, pollution and process heat and financial risk were taken into account.]

The superheated Rankine cycle pressure-enthalpy (P-h) and temperature-entropy (T-s) diagrams are given in Fig. 4 and Fig. 5. By expanding the steam in two stages and reheating the working fluid between the turbine stages; this increases the thermal efficiency and ensures desirable moisture content at final turbine stage (Cengel, 2006). Table 3 summarises the design requirements for the three heat pipe heat exchangers shown in Fig. 3.

\section{THEORETICAL MODELLING}

The HPHE shown in Fig. 2 consists of a housing or container that is charged with the working fluid, and a hot stream section and cold stream section and can be discretised into a number vertical elements, 1 , 2, 3, 4 ..........N-1, to N, as shown in Fig. 6. Each vertical element, in

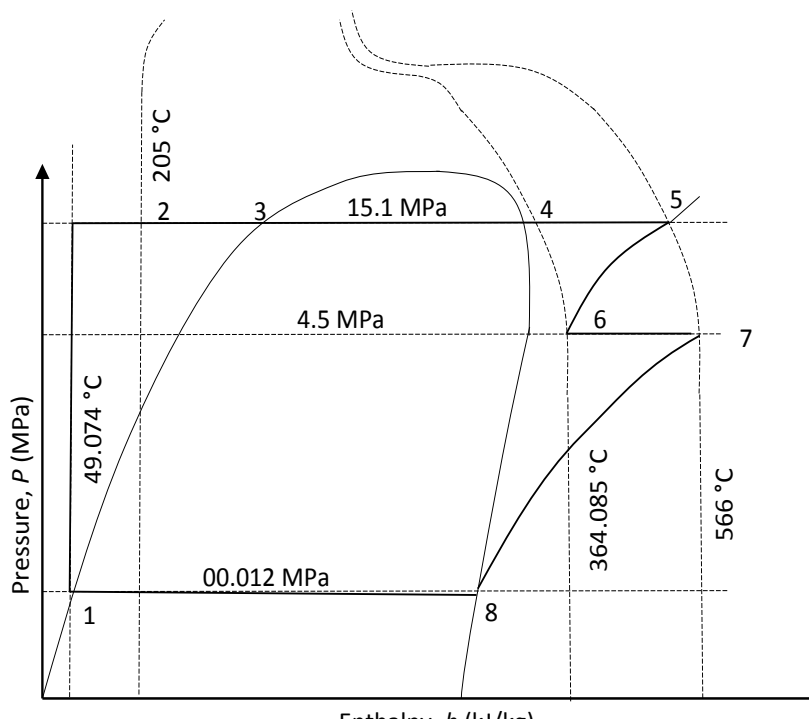

Enthalpy, $h(\mathrm{~kJ} / \mathrm{kg})$

Fig. 4 P-h diagram for superheated reheat Rankine vapour power cycle turn, is subdivided into three one-dimensional control volumes, the hot stream, the two-phase working fluid and the cold stream as shown in Fig. 7.

Consider the energy equation, neglecting potential and kinetic energy and as given by

$\frac{\Delta E}{\Delta t}=(\dot{m} h)_{\text {in }}-(\dot{m} h)_{\text {out }}+\dot{Q}_{\text {in }}-\dot{Q}_{\text {out }}$

Equation 1 may now be applied to each of the three control volumes in each of the $\mathrm{i}=1$ to $\mathrm{N}$ elements shown in Fig. 7. However before the conservation energy can be applied a number of additional assumptions are needed, namely that the vapour is assumed to flow uniformly upwards, and the condensates drops vertically downwards in each element, there is no interfacial thermal resistance between the liquid and vapour; in each vertical element the liquid and vapour are at the same (saturated) temperature, and that although the temperature of the heating and cooling fluids change the fluid pressure does not drop along the length of the pipes.

Applying the conservation of energy, as given by equation 4, to each of the three control volumes in the $i^{\text {th }}$ element to get (Laubscher, 2013)

$$
\begin{aligned}
T_{\text {i hot }}^{t+\Delta t}= & \left(\frac{\rho c_{\mathrm{p}} T^{t}}{\left(\rho c_{\mathrm{p}}\right)^{t+\Delta t}}\right)_{\text {i hot }}+\frac{\Delta t}{\left(\rho A \Delta x c_{\mathrm{p}}\right)_{\text {i hot }}^{t+\Delta t}} \\
& {\left[\left(\rho v A c_{\mathrm{p}} \mathrm{T}\right)_{\text {i hot in }}-\left(\rho v A c_{\mathrm{p}} T\right)_{\text {i hot out }}-\dot{Q}_{\text {i evap }}\right]^{t} }
\end{aligned}
$$

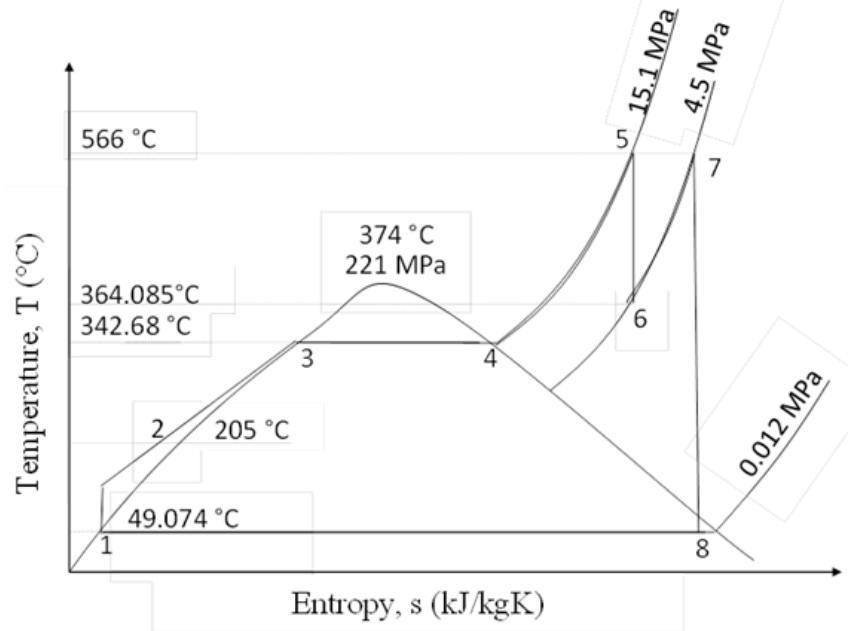

Fig. 5 T-s diagram for superheated reheat Rankine vapour power cycle 


$$
\begin{aligned}
T_{\mathrm{i} \text { cold }}^{t+\Delta t}= & \left(\frac{\rho c_{\mathrm{p}} T^{t}}{\left(\rho c_{\mathrm{p}}\right)^{t+\Delta t}}\right)_{\mathrm{i} \text { cold }}+\frac{\Delta t}{\left(\rho A \Delta x c_{\mathrm{p}}\right)_{\mathrm{i} \text { cold }}^{t+\Delta t}} \\
& {\left[\left(\rho \mathrm{vAc} c_{\mathrm{p}} \mathrm{T}\right)_{\mathrm{i} \text { cold in }}-\left(\rho v A c_{\mathrm{p}} T\right)_{\mathrm{i} \text { cold out }}-\dot{Q}_{\mathrm{i} \text { evap }}\right]^{t} } \\
T_{\mathrm{i} \text { int fluid }}^{t+\Delta t}= & \left(\frac{\rho c_{\mathrm{v}} T^{t}}{\left(\rho c_{\mathrm{v}}\right)^{t+\Delta t}}\right)_{\mathrm{i} \text { int fluid }} \\
& +\frac{\Delta t}{\left(\rho A \Delta x c_{\mathrm{v}}\right)_{\text {i int fluid }}^{t+t}}\left[\dot{Q}_{\text {i evap }}-\dot{Q}_{\text {i cond }}-\dot{Q}_{\mathrm{i} \text { loss }}\right]^{t}
\end{aligned}
$$

Equations 5 to 7 have been presented in an explicit finite difference form suitable for numerical solution and are numerically stable provided the time step is less than $\Delta \mathrm{t}<\Delta \mathrm{x} / \mathrm{v}$; namely provided that a fluid particle does not move a distance greater than the control volume

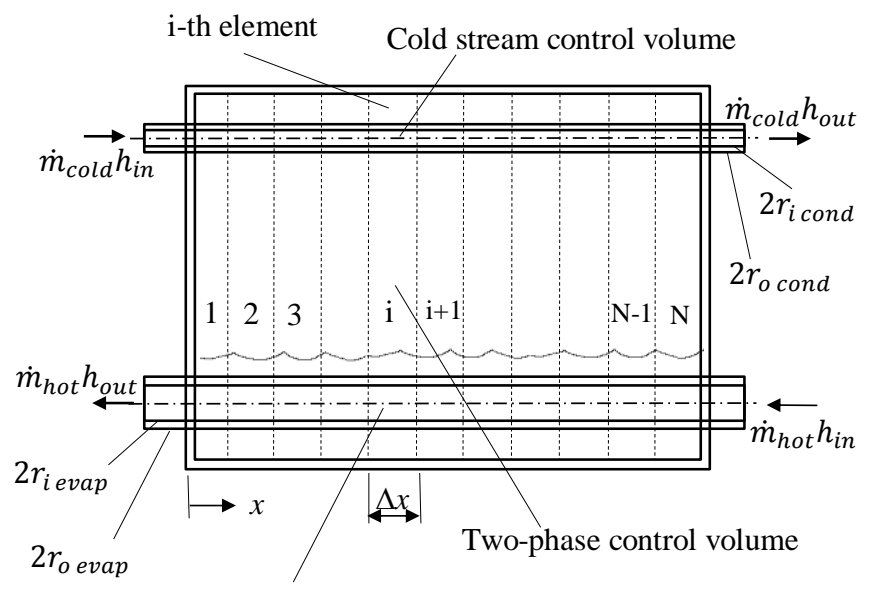

Hot stream control volume

Fig. 6 Discretisation of heat exchanger into a series of elements, each element consisting of a hot heating, two-phase and a cold cooling control volume, as shown in figure 5.

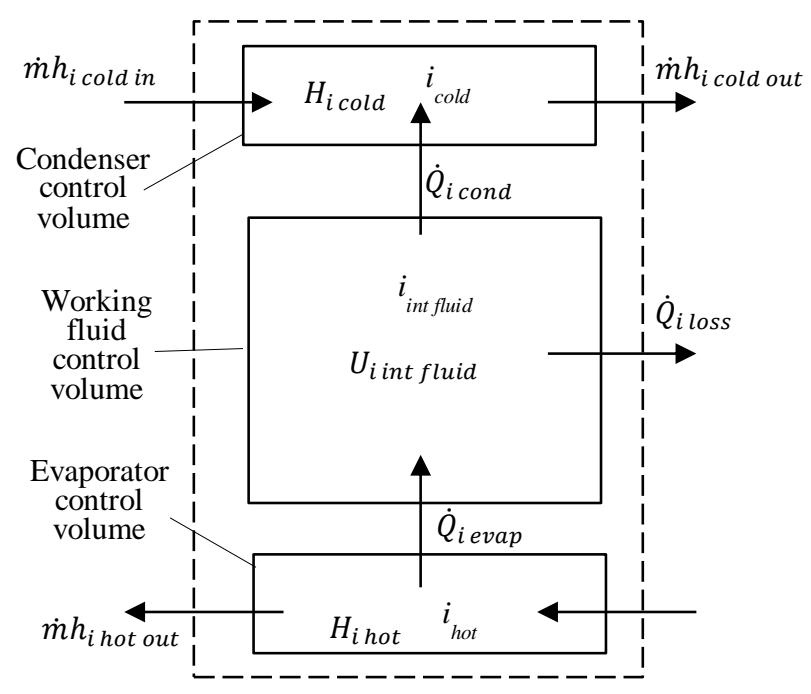

Fig. 7 Depiction of three control volumes constituting an i-th element along the heat pipe heat exchanger.
$\Delta \mathrm{x}$. Note that the density and specific heat at time step $\mathrm{t}+\Delta \mathrm{t}$ are $\rho^{\mathrm{t}+\Delta \mathrm{t}}=\rho^{\mathrm{t}}+(\Delta \rho / \Delta \mathrm{t})^{\mathrm{t}-\Delta \mathrm{t} / 2} \Delta \mathrm{t}$ and

$\mathrm{c}^{\mathrm{t}+\Delta \mathrm{t}}=\mathrm{c}^{\mathrm{t}}+(\Delta \mathrm{c} / \Delta \mathrm{t})^{\mathrm{t}-\Delta \mathrm{t} / 2} \Delta \mathrm{t}$, respectively. The heat transfer rates $\dot{\mathrm{Q}}_{\mathrm{i}}$ from the heating gas to the working fluid and from the working fluid to the cooling liquid are given by equations 5 to 7 , respectively as

$$
\begin{gathered}
\dot{Q}_{\text {i evap }}=\frac{\bar{T}_{\text {i hot }}-T_{\text {i int fluid }}}{\sum R_{\text {evap }}} \\
\dot{Q}_{\text {i cond }}=\frac{T_{\text {i int fluid }}-\bar{T}_{\text {i cold }}}{\sum R_{\text {cond }}}
\end{gathered}
$$

where $\overline{\mathrm{T}}_{\mathrm{i} \text { hot }}$ and $\overline{\mathrm{T}}_{\mathrm{i} \text { cold }}$ are the average hot stream and cold stream control volume temperatures, and assuming a linear temperature distribution along each control volume, the average heating fluid and cooling fluid temperatures are given, respectively as

$\bar{T}_{\text {i hot }}=\left(T_{\text {i hot in }}+T_{\text {i hot out }}\right) / 2$

and

$\bar{T}_{\text {i cold }}=\left(T_{\mathrm{i} \text { cold in }}+T_{\mathrm{i} \text { cold out }}\right) / 2$

$T_{\mathrm{i} \text { intfluid }}$ is the internal fluid control volume temperature and the thermal resistance for the evaporator $\sum R_{\text {evap }}$ and the condenser $\sum R_{\text {cond }}$ are given by

$\sum R_{\text {evap }}=\frac{1}{h_{\mathrm{h}} A_{\mathrm{h}}}+\frac{\ln \left(d_{\mathrm{o}} / d_{\mathrm{i}}\right)}{2 \pi k \Delta x}+\frac{1}{h_{\mathrm{b}} A_{\mathrm{b}}}$

and

$\sum R_{\text {cond }}=\frac{1}{h_{\mathrm{c}} A_{\mathrm{c}}}+\frac{\ln \left(d_{\mathrm{o}} / d_{\mathrm{i}}\right)}{2 \pi k \Delta x}+\frac{1}{h_{\mathrm{c}} A_{\mathrm{c}}}$

where heat transfer area $A=\pi d \Delta x$ and the internal pipe heat transfer coefficients in equations 12 and 13 may be calculated using the Gnielinski correlation and with the Petukhov friction factor (Mills, 1995) as

$h_{\mathrm{h}}=\frac{k}{d} \frac{(f / 8)\left(\mathrm{Re}_{\mathrm{d}}-1000\right) \operatorname{Pr}}{1+12.7(\mathrm{f} / 8)^{1 / 2}\left(\operatorname{Pr}^{2 / 3}-1\right)}$

and

$f=\left(0.790 \ln \operatorname{Re}_{\mathrm{D}}-1.64 D\right)^{-0.2}$

\section{RESULTS}

Solving equations 7,8 and 9 , for steady state conditions, and for the design parameters given in table 3 , possible design specifications for the preheater, superheater and reheater are given in tables 4, 5 and 6, respectively. For the given heat transfer rate, inlet and outlet temperatures of the hot and cold streams the evaporator/condenser tube sizes, evaporator/condenser tube length through heat exchanger core and the number of tubes for each of the three HPHEs have been obtained for a reactor outlet temperature of $750{ }^{\circ} \mathrm{C}$.

The variation of the heat transfer rate as a function of the diameter of the tubes, number of tubes and length of the tubes is shown in figure $8 \mathrm{a}, \mathrm{b}, \mathrm{c}$ and $\mathrm{d}$, respectively for the superheater design given in table 5 . The results are shown in Fig. 8. For each of the graphs shown in Fig. 8 a single parameter, such as evaporator/condenser diameter, was varied while the others, tube length and tube amounts, was kept constant. 

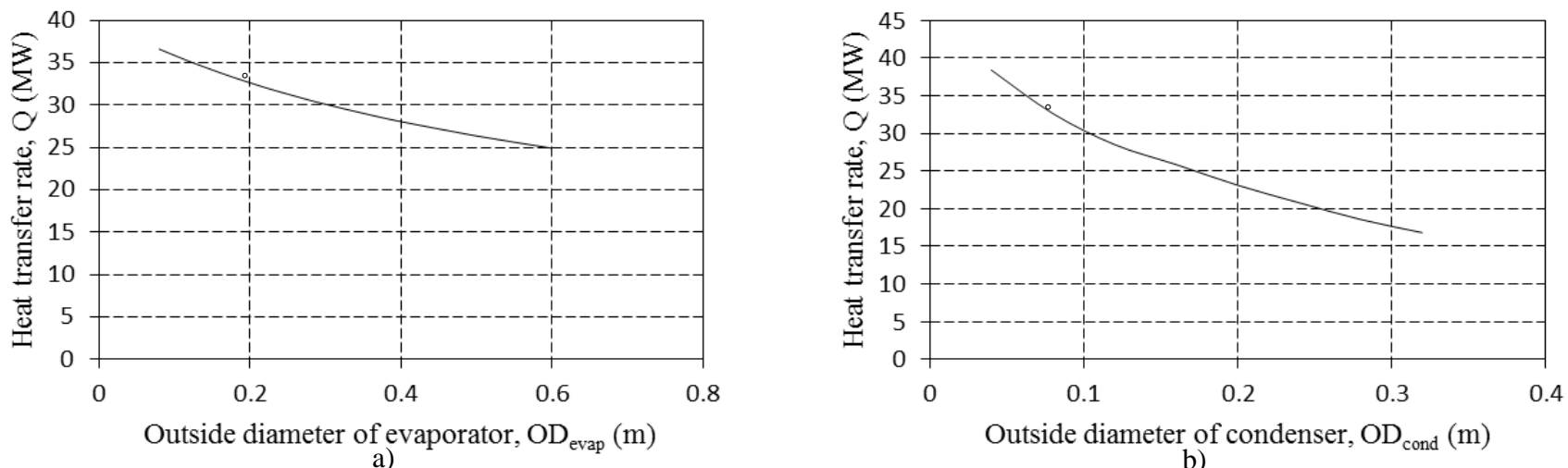

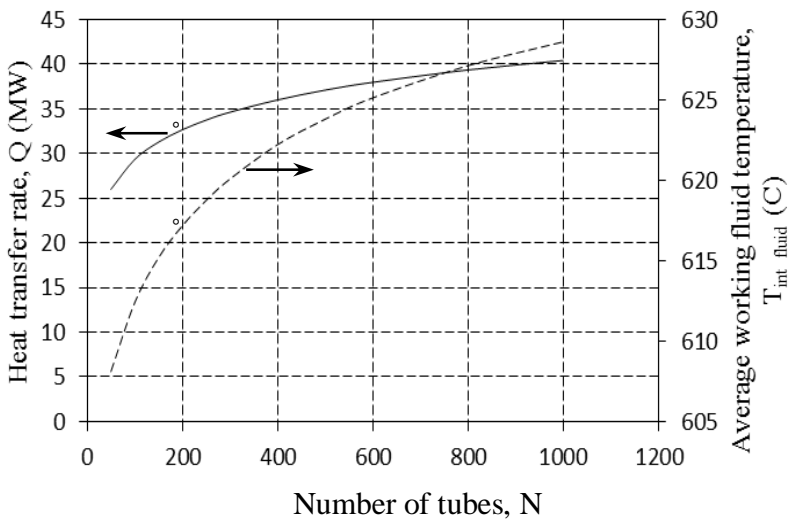

c)

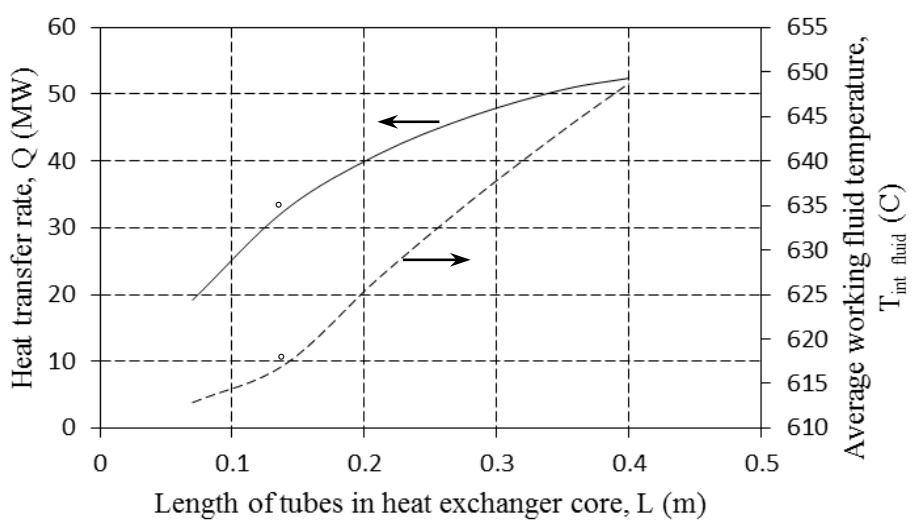

d)

Fig. 8 Sensitivity analysis of the heat transfer rate and working fluid temperature as a function of different HPHE variables (The "•" represents base-case values as per table 5).

From Fig. 8a and Fig. $8 \mathrm{~b}$ it is seen that if the diameter of the condenser or evaporator tubes are increased the heat transfer rate decreases. This is due to the fact that for the thermal resistance due to forced convection within the tubes is; $R_{i} \gg R_{w}, R_{e}$ and then $D \propto 1 / R e$ and $\operatorname{Re} \propto \mathrm{Nu} \propto \mathrm{h}$ and then $\mathrm{h} \propto 1 / \mathrm{R}_{\mathrm{i}}$. From Fig. $8 \mathrm{c}$ it is seen that as the number of evaporator and condenser tubes increase, the heat transfer rate increases. This is because the heat-transfer area increases which resulting in a greater heat transfer rate and increased working fluid temperature within the HPHE. Similarly for Fig. 8d as the HPHE as the tube length is increased so too does the heat transfer area increase.

\section{CONCLUSIONS and RECOMMENDATIONS}

- In Fig. 3 a natural circulation water-tube steam generator and steam drum is shown, but the drum can also be regarded as a type of twophase heat pipe heat exchanger. The hot stream heats the working fluid which in turn heats the water-tubes in which the stems is generated; reminiscent of a typical two phase closed thermosyphontype heat pipe. However, unlike the pre- super- and re-heaters, through which the water is force-circulated, the water flows as a two-phase closed natural circulation loop. In this case the energy and momentum are coupled and hence have to be solved simultaneous and this would require a more complex solution method than is given in section 3. As such the design of the steam generator has not been considered in this paper.

- Sodium would probably be the most suitable working fluid to use in the novel HPHE presented in this paper.

- In general, the Shah boiling correlation will most likely produce the most accurate heat transfer coefficient results.

- Thermodynamic principles and correlations available in the published literature were used to calculate the required heat transfer rates required at each heat exchanger section in the nuclear power plant cycle. In an actual sodium charged heat pipe heat exchanger (HPHE) additional experimental work will be needed to obtain the heat transfer coefficients

- The theoretical model was successfully used to produce a reasonable preliminary design for a heat pipe heat exchanger (HPHE) preheater, a superheated and a reheater (using the projected cycle state points as predicted for the Chinese high temperature nuclear reactor of pebble-bed modular design, also termed the HTR-PM).

\section{NOMENCLATURE}

A area, $\mathrm{m}^{2}$

$c_{\mathrm{p}} \quad$ specific heat, $\mathrm{J} / \mathrm{kg} \mathrm{K}$

$c_{\mathrm{v}} \quad$ specific heat (constant volume), $\mathrm{J} / \mathrm{kg} \mathrm{K}$

$d \quad$ diameter, $\mathrm{m}$

$f \quad$ friction factor

g gravity, $\mathrm{m} / \mathrm{s}^{2}$

$H$ total enthalpy, J

$h$ heat transfer coefficient, $\mathrm{W} / \mathrm{m}^{2} \mathrm{~K}$

$h \quad$ specific enthalpy, $\mathrm{K} / \mathrm{kg}$

$h_{\mathrm{fg}} \quad$ latent heat of vaporization, $\mathrm{J} / \mathrm{kg}$

i element/CV designation

$k$ thermal conductivity, $\mathrm{W} / \mathrm{mK}$

$L \quad$ length, $\mathrm{m}$

$\dot{m}$ mass flow rate, $\mathrm{kg} / \mathrm{s}$

$\mathrm{N}$ number (of tubes)

$P \quad$ pressure, $\mathrm{Pa}$

$P_{\mathrm{r}} \quad$ reduced pressure $P_{\mathrm{r}}=P / P_{\text {crit }}$

$P_{\text {crit }} \quad{ }_{\text {c ritical pressure, } \mathrm{Pa}}$

Pr Prandtl number, $\operatorname{Pr}=c_{\mathrm{P}} \mu_{\mathrm{l}} / k$

$\dot{Q} \quad$ heat transfer rate, $\mathrm{W}$ 


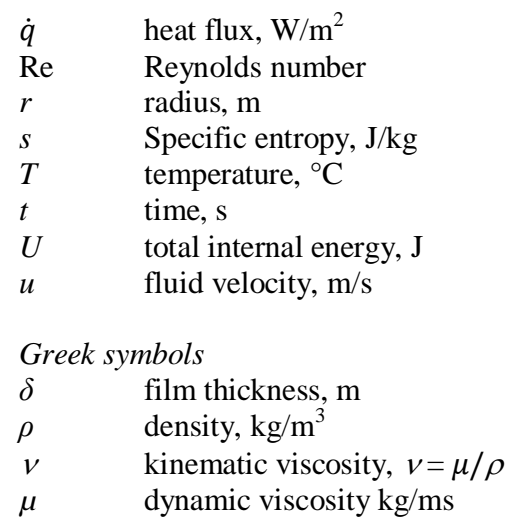

\section{Subscripts}

$\begin{array}{ll}\text { avg } & \text { average } \\ \text { b } & \text { boiling } \\ \text { c } & \text { condensing } \\ \text { cold } & \text { cold stream } \\ \text { cond } & \text { condenser } \\ \text { crit } & \text { critical } \\ \text { d } & \text { diameter } \\ \text { e } & \text { External } \\ \text { evap } & \text { evaporator } \\ \text { hot } & \text { hot stream } \\ \text { ht } & \text { heat transfer } \\ \text { i } & \text { internal } \\ \text { in } & \text { into } \\ \text { int } & \text { internal } \\ \text { l } & \text { liquid } \\ \text { o } & \text { outside } \\ \text { out } & \text { out } \\ \text { s } & \text { surface } \\ \text { sat } & \text { saturation } \\ \text { v } & \text { vapour } \\ \text { w } & \text { wall }\end{array}$

\section{ACKNOWLEDGEMENTS}

Financial assistance from the South African Heat Pipe Association and PBMR Pty LTD is great fully acknowledged

\section{REFERENCES}

Botha F., 2013, Simulation of a Syngas-from-Coal Production Plant coupled to a High Temperature Nuclear Reactor, MSc Eng Thesis, University of Stellenbosch, Stellenbosch, South Africa.

Faghri, A., 1995, Heat Pipe Science and Technology, Taylor and Francis.
IAEA (International Atomic Energy Agency), 1991, Safety Related Terms for Advanced Nuclear Plants, IAEA-TECDOC-626: Vienna.

IAEA (International Atomic Energy Agency), 1996, Progress in Design, Research and Development, and Testing of Safety Systems for Advanced Water Cooled Reactors, IAEA-TECDOC-872, Vienna.

Jousse, A., 2007, Tritium Transport in Very High temperature Reactors for Hydrogen Production, California: University of California at Berkeley.

Laubscher, R., 2013, Development Aspects of a High Temperature Heat Pipe Heat Exchanger for High Temperature Gas-Cooled Nuclear Reactor Systems, MSc Eng, Stellenbosch: University of Stellenbosch, South Africa.

Laubscher, R. and Dobson, R.T., 2013, "Boiling and Condensation Heat Transfer Coefficients for a Dowthem-A Charged Heat Pipe", 11th International Heat Pipe Symposium (11 ${ }^{\text {th }}$ IHPS), Beijing, June 9 - 12.

Laubser, R. and Dobson, R.T., 2013, “Theoretical and Experimental Modelling of a Heat Pipe Heat Exchanger for High Temperature Nuclear Reactor Technology", Applied Thermal Engineering, accepted for publication.

http://dx.doi.org/10.1016/j.applthermaleng. 2013.06.063

Lamarsh, J. R., 2001, Introduction to Nuclear Engineering, Third edition. New Jersey: Prentice Hall.

Mills, A. F., 1995, Heat Transfer, 2nd Edition, Prentice Hall, New Jersey.

Sabharwall, G. P., 2008, Theoretical Design of Thermosyphon for Process Heat Transfer from NGNP to Hydrogen Plant.

Shah, M., 1992, A Survey of Experimental Heat Transfer Data for Nucleate Pool Boiling of Liquid Metals and a New Correlation. International Journal of Heat and Fluid Flow, 13(4). http://dx.doi.org/10.1016/0142-727X(92)90007-V

Thome, J., 2006, Boiling Heat Transfer on External Surfaces in Engineering Data Book III, Wolverine Tube Inc. pp. 9-1 to 9-11.

Cengel, 2006. Thermodynamics: An Engineering Approach, McGraw Hill, New York.

US DOE, 2002, A Technological Roadmap for Generation IV Nuclear Energy Systems, Issued by U.S. DOE Nuclear Energy Research.

Advisory Committee and the Generation IV International Forum, 03GA50034, December 2002.

Zhao Zongrang, 2005, Development and Application of Supercritical Coal-fired Units and CFB Boilers in China, Presentation, Thermal Power Research Institute (TPRI), Cebu, The Philippines, 26 January, 2005. 